\title{
OD SZYMANOWSKIEGO DO MITORAJA. 100 LAT ANTYKU SYCYLIJSKIEGO W POLSKIEJ LITERATURZE I SZTUCE
}

SŁOWA KLUCZOWE: SyCyLIA, ANTYK SYCYLIJSKI, WielKa GRECJA, RZEŹBA, MITOLOGIA

\section{WSTĘP}

Tradycja mitologiczna, postawy, pojęcia i symbole greckiego antyku wykorzystywane były przez twórców kolejnych epok. Sycylia i kolonizująca Italię Wielka Grecja fascynowały i pociągały także naszych autorów. Wybierali się do krainy mitów i herosów, aby naocznie spotkać się z Magna Graecia. Miejsce, krajobraz, zabytki i atmosfera skłaniały ich do refleksji o dawnych bohaterach, sztuce i o przemijaniu. Przeciwstawiali sobie minione losy i współczesne postawy, prowadząc dia$\log$ z przeszłością.

Sycylia była więc miejscem ucieczki od świata współczesnego do dawnego, czasem okrutnego, ale posiadającego pewien porządek. Przeanalizowałam antyczne motywy, symbole i bohaterów występujące w polskiej literaturze, muzyce i sztuce, zaczerpnięte z podróży na Sycylię. Wybrałam jedne z najważniejszych dzieł naszych twórców z okresu 100 lat, w których echa tradycji sycylijskiego antyku pozostawiły znaczący ślad.

\section{MUZYKA. TECSNOTA DO OJCZYZNY}

Podróż poprzez sztukę zainspirowaną Sycylią rozpocznę od pierwszej podróży Karola Szymanowskiego na Wyspę Stońca w kwietniu 1911 roku. „Przed oczami podróżnych przesuwały się mityczne i realne, dotykalne, homerowe pejzaże, stąpali po ziemi Odysa" [Szymanowski 1994: 36] - pisze badaczka jego biografii Teresa Chylińska. „To tu w Messyńskiej Cieśninie, między Scyllą i Charybdą, śpiewały 
Odysowi uwodzicielskie i zdradzieckie syreny, tu na wyspie Ortygii koło Syrakuz rozegrał się dramat nimfy z orszaku bogini Artemidy - Aretuzy, przemienionej w źródlaną wodę” [Szymanowski 1994: 36]. Według Chylińskiej było to „coś więcej niż turystyczne poznawanie świata. To było oczarowanie, odnalezienie obiektu przeczuwanej miłości" [Szymanowski 1994: 36].

Sycylia stała się dla kompozytora już na zawsze ,czasem odnalezionym” [Cyz 2008: 7]. Poznał i zafascynował się wówczas historią i zabytkami Wielkiej Grecji i epoki Normanów. „Dla filozofii Szymanowskiego poznanie Sycylii było epoką” [Iwaszkiewicz 1981 (A): 304] - pisał później Iwaszkiewicz. W Szymanowskim istniała „tęsknota za jakimś innym światem - „Światem Tyrreńskiego Morza”(...) toteż wrażenia z Sycylii i Afryki były niezapomniane przez całe życie" [Iwaszkiewicz 1981 (B): 19].

Do doryckich kolumn na tle morza kompozytor tęsknił jak do ojczyzny: „Morze błękitne, brzeg czerwony, szmaragdowe pola i po brzegu rozsiadłe woskowożółte świątynie, ciągnące się długim szeregiem. Tu mogła płakać Kalipso, tu mogły śpiewać Syreny" [Iwaszkiewicz 1977 (A): 229] - pisał. Szymanowski planował skomponowanie muzyki do baletu, o Przygodach Odyseusza. O tym odysejskim pejzażu marzył także przed śmiercią.

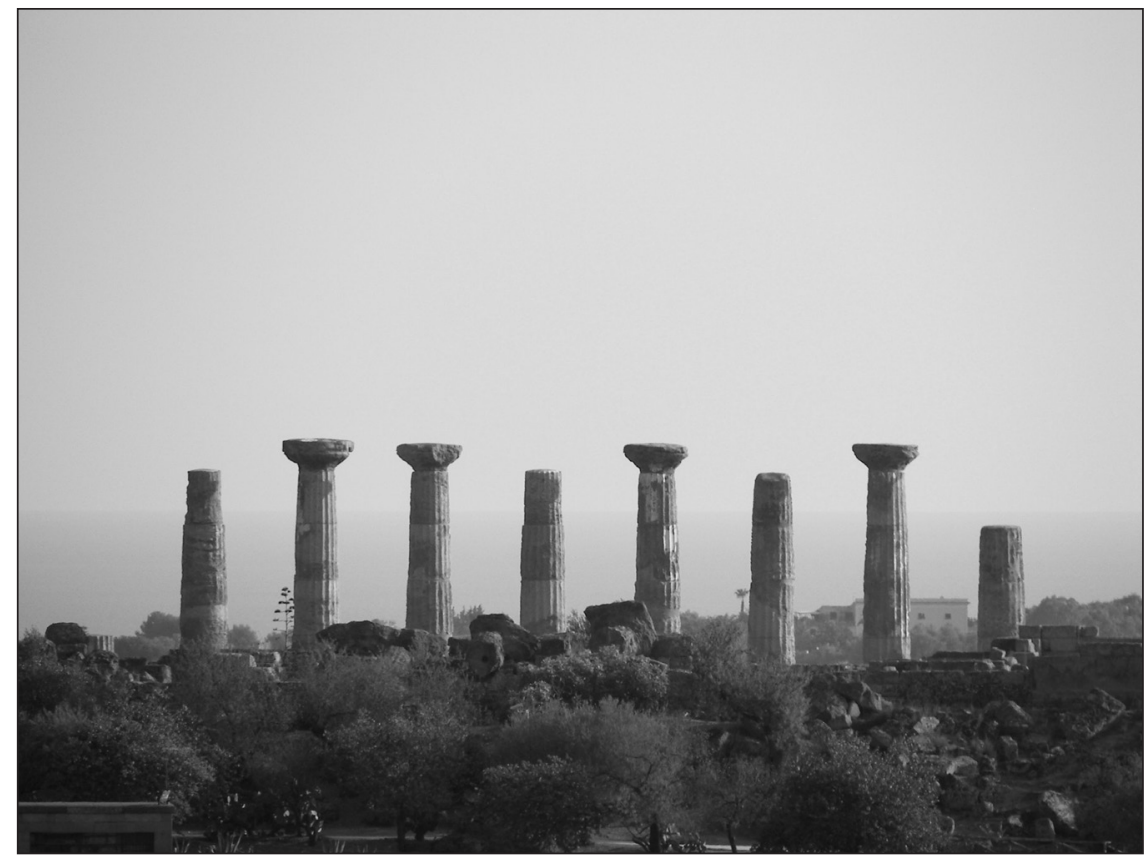

Fot. 1. Agrigento. KrajobraZ OdYSEJSKi (FOT. SDP-EGC)

Po powrocie z Sycylii powstaje opera Król Roger o objawieniu Dionizosa, Boga - „o tajemnicy wiary, o władzy, miłości i rozpaczy, samotności i obłędzie, i śmierci" [Cyz 2008: 5]. Opisane w didaskaliach miejsca i wnętrza są reminiscencjami z podróży - „wszystko jak echo oglądanych przez Szymanowskiego miejsc” 
[Cyz 2008: 8]. Podobne motywy pojawiają się także w powieści Szymanowskiego -Efebos.

Po dwóch podróżach na Sycylię następuje eksplozja twórczości muzycznej kompozytora. Wpływ na to miały „ukochane odysejskie pejzaże, odysejskie mity, odysejskie powroty bez powrotu - wielka poezja Homerowej Grecji” [Szymanowski 1994: 31]. Powstają cykle fortepianowe Mity, Metopy oraz kantaty Demeter i Agawe. Następuje zmiana stylu kompozytora z kręgu wpływów niemieckiego neoromantyzmu kieruje się w stronę francuskiego impresjonizmu. Mity - trzy utwory na skrzypce i fortepian - należą do najsłynniejszych dzieł skrzypcowych Szymanowskiego. Tytuły części stanowią muzyczną postać poszczególnych mitów: Źródto Aretuzy, Narcyz oraz Driady i Pan. W pierwszej odnajdujemy historię nimfy zamienionej w źródło podczas ucieczki przed zalotami bożka rzecznego Alfejosa. W Narcyzie piękny młodzieniec, który zapałał miłością do samego siebie, umiera, nie mogąc oderwać wzroku od własnego oblicza. I w ostatnim Driady i Pan to odniesienie do pogoni fauna za nimfami. Utwory dźwiękowo i technicznie są kwintesencją oryginalnej koncepcji impresjonizmu muzycznego kompozytora - nowego stylu wiolinistycznego. Według krytyków muzycznych, te utwory o niezwykłej kolorystyce brzmieniowej, z nagromadzeniem różnorodnych technik gry dają w efekcie bogatą paletę subtelnych odcieni od liryzmu po ekstazę. Sam kompozytor o nich pisał w liście do skrzypka Roberta Imandta: „〈Tonacja〉 główna 〈płynącej wody〉 w Aretuzie, 〈wody stojącej) w Narcyzie (nieruchoma i przejrzysta powierzchnia wody, w której odbija się piękność Narcyza) - oto są główne linie dzieła (...) W 〈Driadach〉

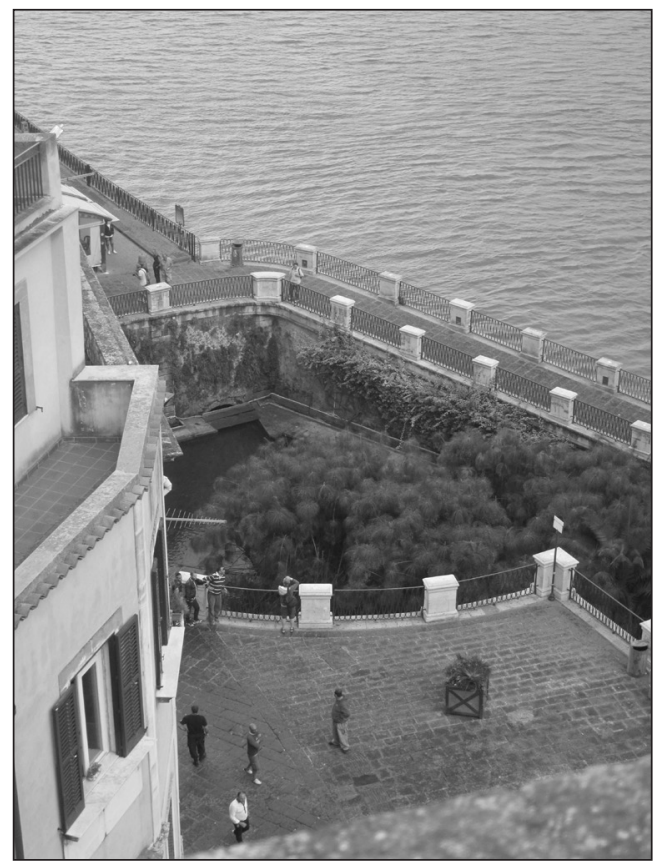

Fot. 2. SyrakuZy. ŹródŁo AretuZy (Fot. SDP-EGC) 


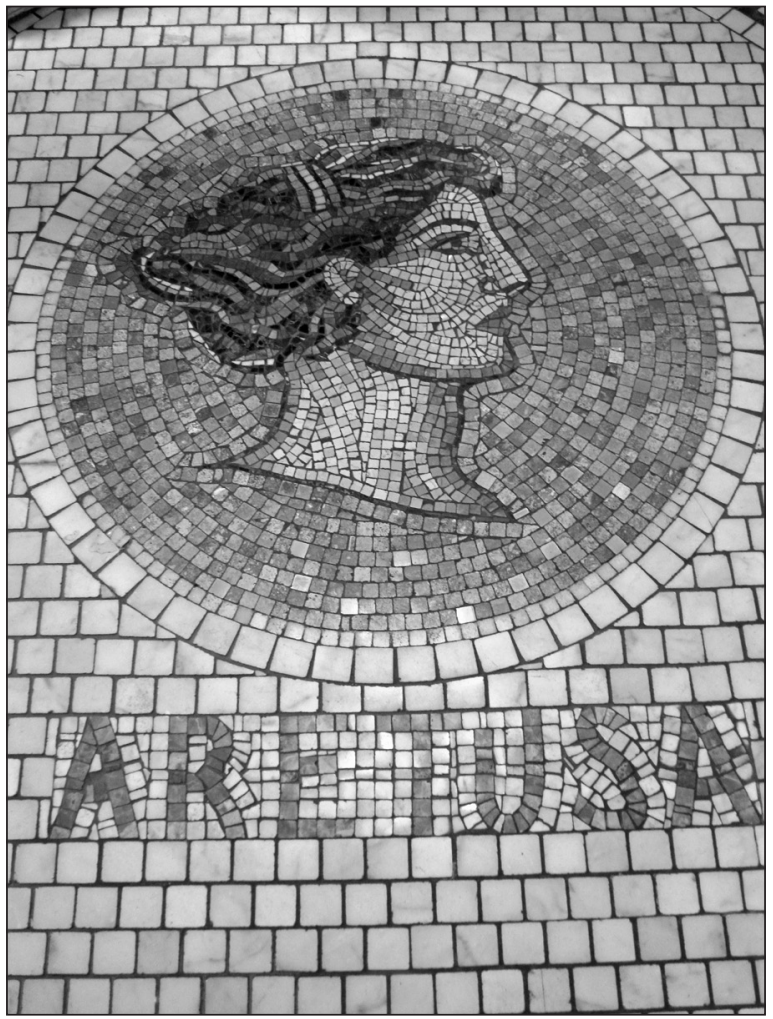

Fot. 3. Syrakuzy. Mityczna AretuZa (Fot. SDP-EGC)

(...) szmery lasu w gorącą letnią noc, tysiące tajemniczych głosów, krzyżujących się ze sobą w ciemnościach - zabawy i tańce Driad. Nagle dźwięk fletu Pana. Cisza i niepokój"1. Impresjonistyczną, swobodną i asymetryczną formą charakteryzuje się cykl poematów fortepianowych Metopy. Jego treść została zaczerpnięta z miłosnych przygód Odyseusza. Kompozytor nie zilustrował ich jednak dosłownie, a raczej wyraził je poprzez nowe brzmienie. Kalipso, Nauzykaa, Wyspa Syren są reminiscencjami z obcowania z metopami z fryzów frontonów świątyń w Selinunte. Te płaskorzeźby z V w. p.n.e., jak pisał Iwaszkiewicz, ,prześladowały Szymanowskiego ${ }^{2}$ głębokim podźwiękiem, aż póki nie zaklął w muzykę tych kształtów plastycznych” [Iwaszkiewicz 1981 (A): 343]. Wyspa syren przywołuje niebezpieczny i czarodziejski śpiew syren, wabiący żeglarzy. Druga część, Kalipso, oparta jest na epizodzie feralnego spotkania Odysa z nimfą z wyspy Ogygii. Ostatni utwór cyklu, Nauzykaa, przywołuje z kolei postać młodej córki króla Feaków i jej losy nieodwzajemnionej miłości.

${ }^{1}$ Cytuję za: Deptuch P. [2002].

${ }^{2}$ Metopy op. 29 - trzy poematy fortepianowe, z których każdy został zadedykowany innej osobie: Wyspa syren - kuzynce Loli Rościszewskiej, Kalipso - siostrze Annie, a Nauzykaa - Mariannie Davidoff. Za życia kompozytora wykonywał je m.in. Artur Rubinstein. 
Przez krytyków cykl Metopy uznawany jest za jeden z najbardziej „modernistycznych" utworów w historii muzyki polskiej początku XX wieku. A sam Szymanowski określał tę muzykę jako europejską: „Nie należy w mojej muzyce szukać kosmopolityzmu, czy gorzej jeszcze - internacjonalizmu. Można w niej znaleźć jedynie 'europejskość', ta zaś nie zaprzecza polskości; mamy do niej prawo" [Makowska 2013].

\section{LIRYKA. SONETY I WIERSZE}

Nad źródło Aretuzy w Syrakuzach trafił po kilkunastu latach także Iwaszkiewicz. Wyobrażał je sobie, słuchając opowieści starszego kuzyna Karola. Będąc tam, nie szukał jednak w jego wodach odbicia nimfy uciekającej przed Alfejosem. Mimo że "gładkie i tajemnicze lustro wody z ciemnymi perukami papirusów - milczało" - on słyszał. Słyszał „dźwięki wysokie i bolesne, natężone hamowaną namiętnością” [Iwaszkiewicz 1981 (A): 375]. Znał je z Mitu - Źródło Aretuzy Szymanowskiego ${ }^{3}$. Ta muzyka i wieczory nad źródłem stały się poetycką inspiracją. Powstaje drugi z cyklu sonetów sycylijskich. Całość to owoc pierwszej podróży na „Wyspe słońca, to spotkanie z wyspą, z mitem swojej młodości" [Zaworska 1980: 86]. Dla Iwaszkiewicza, jak dla romantyków, podróż stała się wielką przygodą duchową, sposobnością poznania siebie i własnej postawy wobec świata. Jak podkreśla Helena Zaworska, Sonety sycylijskie są, podobnie jak Sonety Krymskie Mickiewicza, „nie tylko obrazem podróży, próbą oddania w słowie urody pejzażu i zabytków, ale przede wszystkim - próbą utrwalenia własnej, jedynej i niepowtarzalnej reakcji na te zjawiska, skonfrontowania całości swojego życia z nowym doświadczeniem" [Zaworska 1980: 86]. W ciszy opuszczonych świątyń „zdaje się możliwe usłyszenie głosu nadającego sens całemu życiu" [Zaworska 1980: 86].

W sonetach za Iwaszkiewiczem podążamy poetyckim szlakiem poprzez ruiny Segesty i Agrigento. Podobnie jak u Szymanowskiego metopy selinunckie zapadają głęboko w pamięć pisarza. Odwiedza je w palermitańskim muzeum podczas każdej wizyty (Sycylię odwiedza podczas całego życie trzynastokrotnie). Te kamienne postaci sprzed dwóch i pół tysiąca lat uchwycone w ruchu zainspirowały go do napisania sonetów: o zaślubinach Hery i Zeusa (I bierze Zeus jej rękę. I prowadzi w toże), o umierającej królowej amazonek Hipolicie - od ciosu Heraklesa oraz o Dianie zadającej śmierć Akteonowi (Kto spojrzat pięknu w oczy, ten śmiercia umiera [Iwaszkiewicz 1977 (B): 403]).

Segestańskiej świątyni Iwaszkiewicz poświęcił także ostatni ze swoich sycylijskich sonetów:

„Twoich kolumn ognisko w ciężkim słońcu płonie,/ Na zielonej przełęczy, samotnico, trwasz./ Góry niebieskie, niebo sine trzyma straż,/ Kiedy uniosą słońce w noc miedziane konie; Umierasz wiecznym życiem w milczenia koronie/ Mówiąc samotnej nocy greckie 'Ojcze nasz”' [Iwaszkiewicz 1977 (B): 404].

${ }^{3}$ Prawykonanie utworu odbyło się w Humaniu, na skrzypcach grał Paweł Kochański, a akompaniował mu sam kompozytor. Wówczas utwór nosił nazwę La Source enchanté (Źródło zaczarowane). 


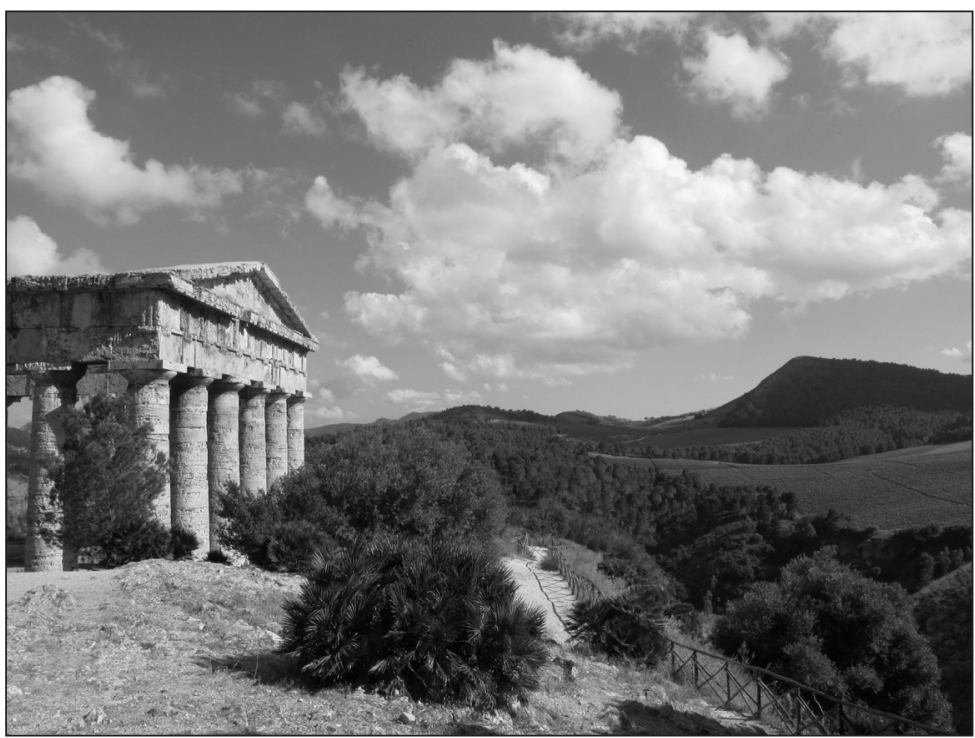

Fot. 4. Segesta. Świątynia (Fot. SDP-EGC)

Sonet wstępny, rozpoczynający cykl 11 wierszy, który jest apostrofą do Szymanowskiego, kompozytora, kuzyna i przyjaciela, napisany został niedługo po jego śmierci i jest hołdem złożonym mu przez Iwaszkiewicza, „echem jednoczącym oczarowania Sycylią, podziękowaniem za otwarcie oczu wyobraźni na tę szczęśliwą wyspę" [Cyz 2008: 8].

Należy dodać, że Iwaszkiewicz poświęcił Sycylii także dzieła prozatorskie: Książę o Sycylii, zadedykowaną Józefowi Rajnfeldowi, przyjacielowi, z którym po raz pierwszy przemierzał Sycylię w 1932 r., oraz część w książce Podróże do Włoch. Sycylijskie motywy antyczne wykorzystał także w opowiadaniach: Powrót Prozerpiny i Hotel Minerwa.

Antyk głęboko wrósł w świadomość i wyobraźnię Romana Brandstaettera, stanowiąc integralną cześć jego świata poetyckiego [Stabryła 1976]. W powojennej twórczości pisarza, szczególnie związanego z kulturą i tradycją śródziemnomorską, wyróżnia się nurt antyczny: poematy i dramaty. Jak pisze Stanisław Stabryła, twórczość liryczna Brandstaettera ,wyrosła bez wątpienia w kanonach klasycznej estetyki poetyckiej z jej dążeniem do zachowania harmonii i szlachetnej równowagi jako artystycznego odbicia stabilności świata i jego spraw" [Stabryła 1976: 211].

Z kolei Wojciech Kaczmarek pisze o jego poszukiwaniach „sensu świata i sensu człowieka, gdzie odnajdywał pierwotne, zasadnicze rysy stworzenia: ład, piękno i miłość, która jest cechą Boga" [Kaczmarek 2013]. Liryka antyczna Brandstaettera z okresu powojennego zawarta jest głównie w tomiku Dwie muzy. W nim osobny rozdział poświęcony jest impresjom z podróży na Sycylię. 


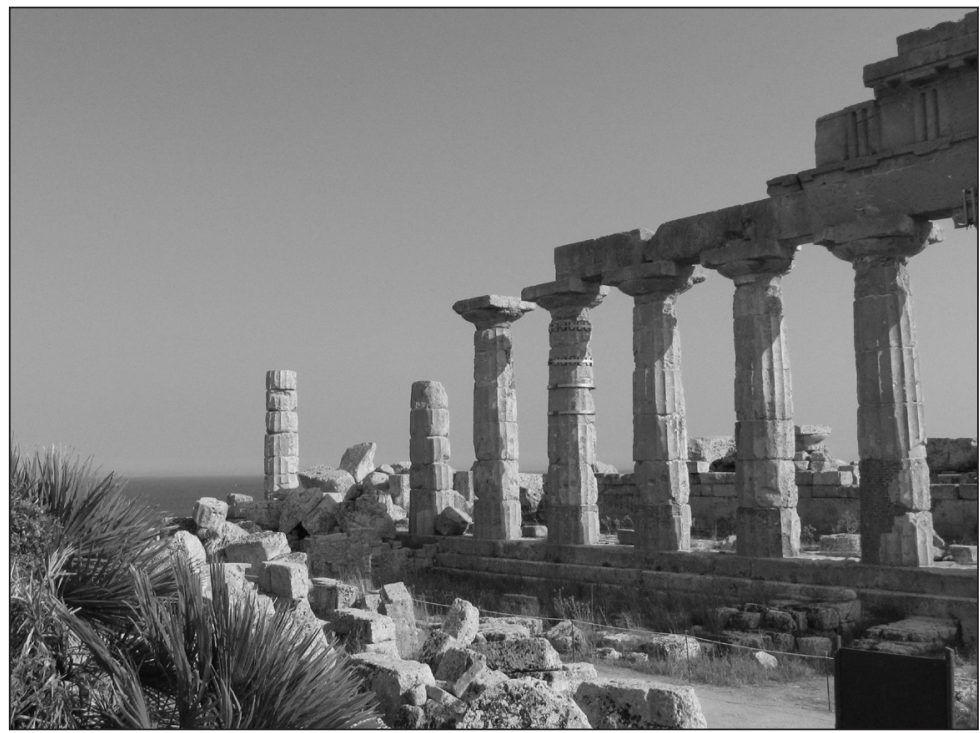

Fot. 5. Selinunte. Ruiny ŚWIĄTYNi C (FOT. SDP-EGC)

Podróż w blasku księżyca, w cieniu Etny, wśród skał cyklopowych, gdzie „będziemy słuchali/ Koncertu faunów/ Na zielonej darni” [Brandstaetter 1965: 221].

Wśród ruin poeta czuje oddech starożytnych. „W korzeniach ich kolumn/ Płynie krew / Bogów/ Słyszę jej/ Ciemne i niespokojne/ Krążenie" [Brandstaetter 1965: 261] - pisał. Przechadza się po ciepłych od słońca pozostałościach świątyń „Cmentarza bogów” w Selinunte, gdzie pozostało morze strzaskanych kolumn i frontonów, gdyż „bogowie/ Nie chcą wrócić/ Do życia./ Wolą być ruinami” [Brandstaetter 1965: 258]. Dostrzega samotność dawnej świątyni i teatru w Segeście: „Po świątyni/ Przechadza się cień/ Nieznanego boga/ Po teatrze/ Przechadza się cień/ Zapomnianych gestów/ Nic więcej nie pozostało/ Z boga,/ Teatru/ I aktorów" [Brandstaetter 1965: 256-257]. W Taorminie zaś patrzy jak „Samotne kolumny/ wypowiedziawszy do końca/ Swoje monologi/ Zastygły w nieruchomych pozach" [Brandstaetter 1965: 284]. Słucha też „akustyki wieków” dawnych Greków w Uchu Dionizosa w Syrakuzach. Komentuje spotkania ze światem sztuki, jak np. w wierszu o Heraklesie i amazonce, zainspirowany metopą z Selinuntu.

Wielkie postaci dziejów antycznych i bohaterowie mitów zyskują w jego poezji często nieoczekiwane interpretacje i znaczenie - pisze Stanisław Stabryła. Antyk u Brandstaettera stanowi, jak podkreśla, ,szczebel do zrozumienia świata współczesnego" [Stabryła 1976]. W syrakuzańskim teatrze, szukając śladów Ajschylosa, znajduje swoją współczesność. W wierszu o zwycięstwie poezji nad wojną (Ateńczyk i wiersze Eurypidesa) zadaje pytanie o miejsce poezji. 


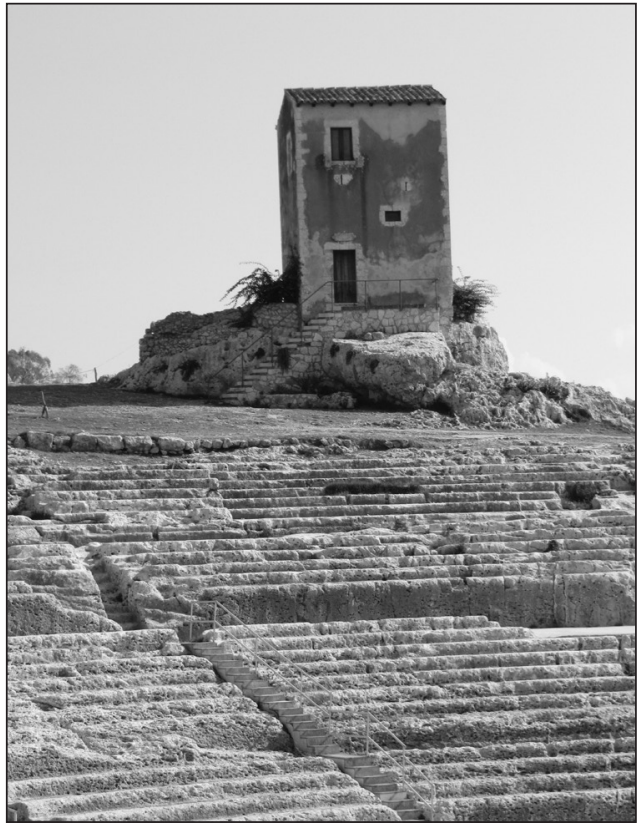

Fot. 6. Syrakuzy. Teatro Greco (Fot. SDP-EGC)

\section{DRAMAT. Odys z WySPY SŁoŃca}

Jak podkreśla Stabryła, w dramatach Brandstaettera mit grecki stanowił tworzywo i model świata współczesnego, a z drugiej strony umożliwiał budowanie metafor o znaczeniu nieprzemijającym i uniwersalnym [Stabryła 1976: 212]. W jednoaktowym dramacie Odys płaczacy Brandstaetter interesująco podejmuje wątek oczekiwania Penelopy i powrotu Odysa do Itaki. Jest on punktem wyjścia do rozważań o pogoni człowieka za bogactwem i wpływami, poprzez krew i okrucieństwo, których konsekwencją jest destrukcja osobowości. W dramacie Brandstaetter rezygnował z wydarzeń homerowego eposu. W swojej sztuce zaprezentował historię Odysa w sposób nieprawdziwy. Oryginalną cecha utworu są właśnie przemiana i niezgodności - nowa tożsamość Odysa i jego ostateczne rozstanie. O tym, jak to wpłynęło na wizerunek Odysa, pisze Wojciech Kaczmarek:

W jego opowieści pojawia się bowiem dwóch Odysów: ten bohaterski, owiany sławą zdobywcy Troi, pełen sukcesu, bogactw, mordujący wrogów i sycący się zwycięstwem, oraz drugi, dokonujący refleksji nad swoim życiem, bo zobaczył krew na swoich rękach, bo „wpuścił” konia trojańskiego także do swojego serca i zaznał śmierci ducha, śmierci swojego ja, śmierci ontycznej, która uczyniła jego życie bezsensem. Przemiana, jaka się w nim dokonała, miała związek z doświadczeniem śmierci - tej zadawanej przez Odysa i tej, którą nosił w sobie, ,śmierci ducha” [Kaczmarek 2013: 86].

Brandstaetter tak pisze o nowym Królu Itaki: 
Jestem Odys,/ Który nie zabił ani jednego człowieka/ I nie zburzył ani jednej Troi/ I nie podpalił ani jednego domu/ I nigdy nie dźwigał miecza (...). Jestem Odys,/ Który kocha pokój i dojrzałe owoce,/ Sieci pełne ryb i pług, i chleb, i winobranie/ I w milczącym szacunku chyli głowę przed każdą Hekubą/ I przed każdym Priamem [Brandstaetter 1986: 439].

Jak pisze Kaczmarek,

łzy Odysa są ważnym składnikiem jego życiowej przemiany. Otrzymał nowe życie nie na zasadzie jakiegoś eskapizmu, ale „odarcia się” z tego, co go dotąd stanowiło: niezwyciężonego herosa, przebiegłego stratega, bezwzględnego władcy. Zobaczył wówczas prawdę o sobie, o człowieku, który wyrządza zło, zabija, sieje zgorszenie, jest niesprawiedliwy i pragnie zemsty. Łzy obmywają go, tak jak wody chrztu obmywają ze zmazy grzechu i rodzą do życia nowego [Kaczmarek 2013: 89-90].

Dlatego według Dariusza Kuleszy antyczny dramat Brandstaettera można określić jako dramat chrześcijański [Kulesza 1999: 108].

\section{RZEŹBA. Powrót do dOMU}

Po podróżach i powstawaniu dzieł polskich literatów i kompozytora swoje prace, wyrosłe z antyku, konfrontuje w mitycznej scenerii Sycylii polski rzeźbiarz - Igor Mitoraj. Wiosną 2011 roku otwarto w Parku Archeologicznym w Agrigento jego plenerową wystawę.

Nowe-stare rzeźby stały się na osiem miesięcy wspaniałym towarzystwem dla starożytnego tła sprzed 2,5 tysiąca lat dawnego Akragas, a dzisiejszego Agrigento.

Mitoraj był współczesnym artystą, zapatrzonym w korzenie przeszłości, a jednocześnie poszukującym nowej estetyki i własnej formy wyrazu. Odwoływał się do warsztatu mistrzów Michała Anioła czy Antonia Canovy. Mówił że, jego związek ze sztuką klasyczną, wynikał ,z odczuwania silnej potrzeby odnalezienia trwałych punktów odniesienia, niezmiennych wartości, korzeni cywilizacji, w której wzrastał" [Sarzyński 2007].

Dlatego też bywał często w Helladzie. Miał świadomość wszystkiego, co bezpowrotnie odeszło, ale wierzył, że istnieje pomost do przeszłości. „Chciałem wyrazić mój podziw i respekt dla Południa, gdzie rodziła się wielka kultura, cywilizacja, i sztuka. Od starożytności greckiej po nasze dni Sycylia wiele mnie nauczyła. Ta cześć świata ma wielki, przyprawiający o zawrót głowy urok" - wyjaśniał przed otwarciem wystawy [Mitoraj 2011].

Do tego czasu jego monumentalne dzieła mierzyły się głównie ze współczesną architekturą metropolii. W Dolinie Świątyń powróciły do krainy mitów i jak mówił sam autor - „powróciły do domu”. Mitoraj był zafascynowany kamieniem. Jego „oddech” poczuł w Grecji i we Włoszech. „Ktoś powiedział, że kamienie oddychają i że ten ich oddech jest jak śpiew syren, bo wabi i uwodzi, żeby potem zgubić. Ale ja nie dałem się zgubić, a przynajmniej nie wydaje mi się, żeby tak było" [Costantini 2003: 43]. 


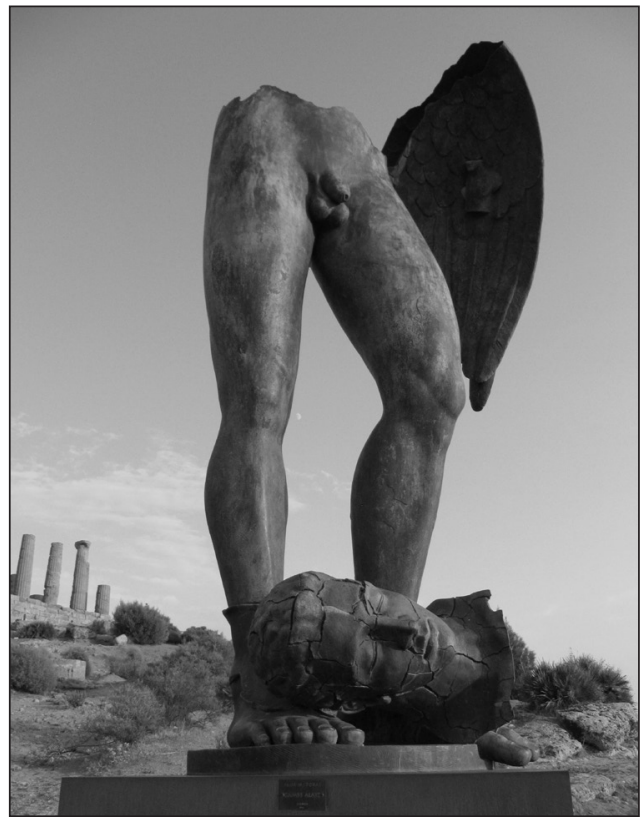

Fot. 7. Agrigento. I. Mitoraj - Nogi uskrzydlone (Fot. SDP-EGC)

Artysta twierdził, że lubi plenery i przestrzenie, które dają inne możliwości kontaktu ze sztuką. Niwelują bariery jakie są przed odbiorcą w muzeum. „Rzeźby są trójwymiarowe i potrzebują przestrzeni, żeby mogły żyć, oddychać, podobnie jak żywe organizmy" [Costantini 2003: 101].

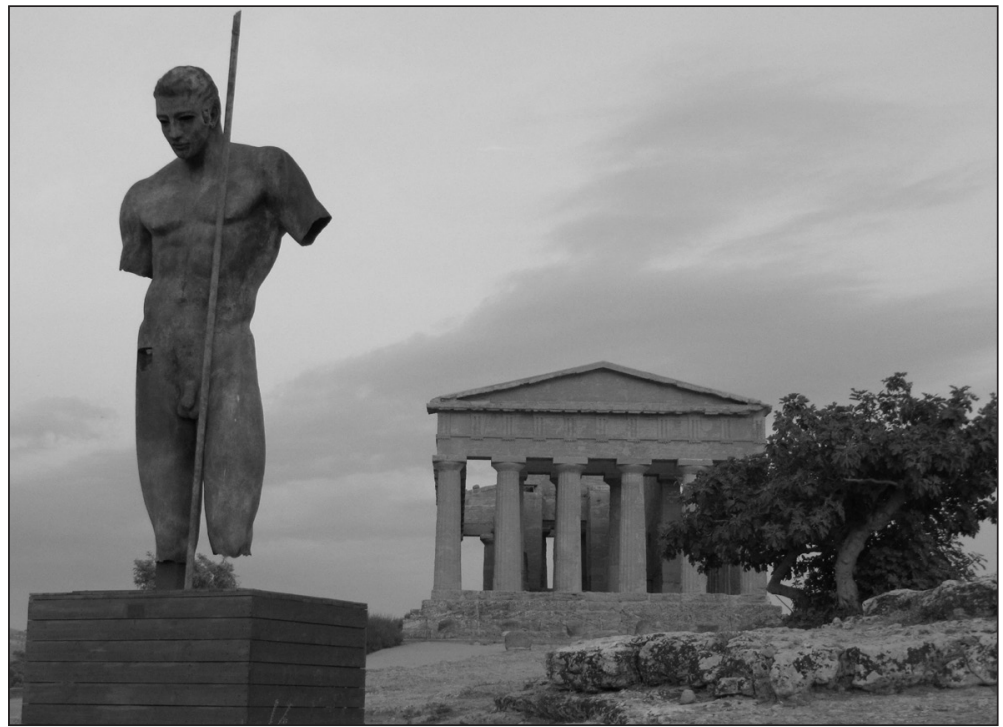

Fot. 8. Agrigento. I. Mitoraj - Dedal (Fot. SDP-EGC) 
W Agrigento była to kolejna, ale zarazem największa i najdłuższa wystawa prac artysty na Sycylii (17 rzeźb). Tam wśród doryckich kolumn i starożytnego pyłu rozsiadły się mitologiczne postacie. Puste ruiny doryckich świątyń zaludnili ich dawni bohaterowie: Dedal, Ikar i Ikarie. Złamane ikarowe skrzydła, potrzaskane torsy zdruzgotanego Dedala. Do tych postaci bezpośrednio związanych z mitologią sycylijską dołączyli Tyndareos i Eros. I, jak u Mitoraja, postacie okaleczone, obandażowane, kryjące przeszłość i tajemnicę.

\section{ZAKOŃCZENIE}

Wybrane i przedstawione przykłady z twórczości artystów pokazują dobitnie istotne wpływy kultury antyku Sycylii na polską literaturę i sztukę w ciągu minionych 100 lat. Podkreślają jej aktualność jako niewyczerpanego źródła inspiracji. Przedstawiają możliwości ich różnorodnego odbioru w tak odmiennych tworzywach artystycznych jakimi są literatura, muzyka i sztuka. Także ich przenikania się i wspólnych odniesień. Pokazują wreszcie, że zainteresowania i tematyka twórców nie były przypadkowe i świadczą o nierozerwalnym związku naszej kultury z kulturą Śródziemnomorza. Są również dowodem na trwałe miejsce naszych twórców w kulturze tego kręgu.

\section{Bibliografia}

Brandstaetter R. [1965], Dwie muzy, Instytut Wydawniczy PAX, Warszawa.

Brandstaetter R. [1986], Odys płaczacy, [w:] Dramaty, Instytut Wydawniczy PAX, Warszawa.

Costantini C. [2003], Blask kamienia, Igor Mitoraj, Wydawnictwo Literackie, Kraków. Cyz T. [2008], Powroty Dionizosa, „Zeszyty Literackie”, Warszawa.

Deptuch P. [2002], Karol Szymanowski, Mity op. 30, http://culture.pl/pl/dzielo/karol-szymanowski-mity-op-30 [dostęp: 20.09.2016].

Iwaszkiewicz J. [1981 (A)], Książka o Sycylii, [w:] Podróże, t. I, Czytelnik, Warszawa.

Iwaszkiewicz J. [1981 (B)], Spotkania z Szymanowskim, PWM, Kraków.

Iwaszkiewicz J. [1977 (A)], Podróże do Włoch, PIW, Warszawa.

Iwaszkiewicz J. [1977 (B)], Wiersze, t. I, Czytelnik, Warszawa.

Kaczmarek W. [2013], Dziedzictwo antyku w twórczości Romana Brandstaettera, „Roczniki Humanistyczne”, t. LXI, zeszyt 3.

Kulesza D. [1999], Tragedia ukrzyżowana, Wyd. Uniwersytetu w Białymstoku, Białystok.

Makowska M. [2013], Europejskość nie zaprzecza polskości. Mamy do niej prawo. Karol Szymanowski - artysta, Polak, Patriota, Zeszyty Naukowe Towarzystwa Doktorantów UJ „Nauki Humanistyczne”, Nr specjalny 4 (1/2013). 
Mitoraj I. [2011], Igor Mitoraj Parco Archeologica Valle dei Templi di Agrigento, katalog wystawy, Agrigento.

Sarzyński P. [2007], Duch w marmurze, „Polityka” nr 36.

Stabryła S. [1976], Inspiracje antyczne w liryce Romana Brandstaettera, „Meander", nr 5-6.

Szymanowski K. [1994], Pisma, t. II, Pisma literackie, PWM, Kraków.

Zaworska H. [1980], Sztuka podróżowania, Wydawnictwo Literackie, Kraków.

\section{Fotografie}

Fot. 1. Agrigento. Krajobraz odysejski (fot. SDP-EGC)

Fot. 2. Syrakuzy. Źródło Aretuzy (fot. SDP-EGC)

Fot. 3. Syrakuzy. Mityczna Aretuza (fot. SDP-EGC)

Fot. 4. Segesta. Świątynia (fot. SDP-EGC)

Fot. 5. Selinunte. Ruiny świątyni C (fot. SDP-EGC)

Fot. 6. Syrakuzy. Teatro Greco (fot. SDP-EGC)

Fot. 7. Agrigento. I. Mitoraj - Nogi uskrzydlone (fot. SDP-EGC)

Fot. 8. Agrigento. I. Mitoraj - Dedal (fot. SDP-EGC) 